\title{
萎縮ラットヒラメ筋のデスミン発現に及ぼす熱ストレス効果
}

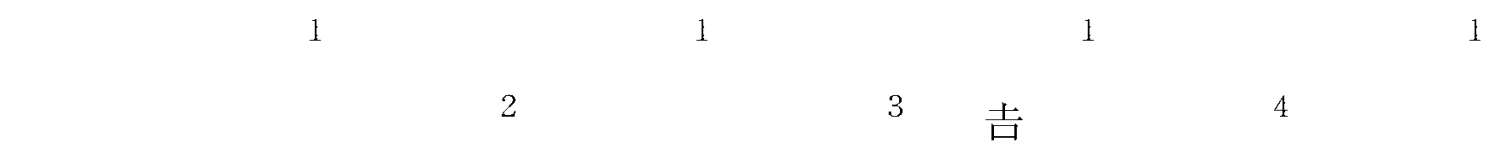

\section{EFFECT OF HEAT STRESS ON DESMIN EXPRESSION IN ATROPHIED SOLEUS MUSCLE}

\author{
TAKao Sugiura, Tsubasa Shibaguchi, Toshinori Yoshihara, Yuki Yamamoto, \\ KATSUMASA GOTO, HiSASHI NAITO and TOSHITADA YOSHIOKA
}

\begin{abstract}
In the present study, we investigated the effect of heat stress on disuse atrophy from changes in the muscle protein levels of desmin and calpain. Wistar strain female rats (6-8 months old) were randomly assigned to two experimental groups: control (C) and heat stress (H). One hindlimb of all animals was immobilized in plantar flexion with plaster. Before immobilization, animals in $\mathrm{H}$ group were placed in a heat chamber $\left(42^{\circ} \mathrm{C}\right.$ for $\left.60 \mathrm{~min}\right)$. Following 6 days of immobilization, the soleus muscles were removed and analyzed. Although immobilization resulted in significant muscle atrophy in all experimental animals, the soleus weight-to-body weight ratio in immobilized limbs of $\mathrm{H}$ group was significantly higher compared to that of $\mathrm{C}$ group. Expression of desmin and HSP72 in the atrophied soleus muscle from $\mathrm{C}$ group was significantly lower compared with the contralateral muscle; but this was not the case in $\mathrm{H}$ group. Further, in $\mathrm{C}$ group, the ratio of autolyzed calpains I increased significantly in the atrophied muscle compared to the contralateral muscle. These results show that the effect of heat stress on disuse skeletal muscle atrophy is attributed to the decreasing degradation of desmin by suppressing the activation of calpain.
\end{abstract}

key word : desmin, calpain, atrophy, heat stress

(Jpn. J. Phys. Fitness Sports Med. 2010, 59:167 174)

$$
\text { I . 緒言 }
$$

骨格筋は不活動によって萎縮する．これは, タン パク質分解と合成のバランスが崩れ，分解が合成を 上回ることによって引き起こされる゙'. 不活動によ るタンパク質分解促進の要因として, 酸化ストレス の増大や, 弚れに伴う細胞内カルシウムイオンの増 加などがあげられている ${ }^{2 \sim 4)}$. 細胞内に増加したカ ルシウムイオンは, カルシウム依存性のプロテアー ゼであるカルパインを活性化する ${ }^{5,6)}$. 活性化した カルパインは, Z線に局在し隣接する筋原線維やサ ルコメアを結合しているデスミンなどの細胞骨格を
分解する ${ }^{5,7,8)}$.デスミンノックアウトマウスでは， 対照マウスと比較して筋損傷を起こしやすく，損傷 後の再生過程において筋原線維の再生が不完全であ ることが報告されている ${ }^{9)}$.これらのことから，デ スミンは筋原線維の構造を正常に維持するばかり か，筋再生においても構造上不可欠なタンパク質で あると言える 。

これまで, 不活動によりカルパイン活性がえ進 $し^{10)}$, デスミン量は低下し，光れらの間には負の相 関が見られることが報告されている゙1).したがって， カルパインによるデスミンの分解を抑制することが できれば，筋原線維の崩壊を防ぐことで，筋萎縮を

\footnotetext{
1) 山口大学教育学部スポーツ健康科学教室 干753-8531 山口市大字吉田1677-1

2)豊橋創造大学リハビリテーション学部 干440-8511 愛知県豊橋市牛川町松下 20-1

3)順天堂大学スポーツ健康科学部運動生理学教室 干270-1695 千葉県印旛郡印旛村平賀学園台 1-1

4)弘前学院大学

干036-8577 青森県弘前市稔町 13-1
}

Department of Exercise and Health Sciences, Faculty of Education, Yamaguchi University, Yamaguchi 753-8513, Japan Laboratory of Physiology, Toyohashi SOZO University, Toyohashi 440-8511

Department of Exercise Physiology, School of Health and Sports Science, Juntendo University, Inba, Chiba 270-1695, Japan Hirosaki Gakuin University, Hirosaki, Aomori 036-8577, Japan 
軽減できると考えられる．

近年，熱ストレスを負荷することにより不活動や 不動化による筋萎縮を抑制することが種々の萎縮モ デル動物を用いて報告されている ${ }^{12,13)}$.この機序 の一つとして，熱ストレスによって誘導される熱シ ヨックタンパク質(HSP)が持つ，損傷したタンパク 質の凝集抑制，一部変性したタンパク質の修復機能， さらには抗酸化能力などの機能により, タンパク質 分解が抑制されることによると考えられている ${ }^{14)}$. このように，熱ストレス負荷はタンパク質の分解抑 制への関与が示唆されていることから, 熱ストレス 負荷によって誘導される HSP が, 先に述べたカルパ インの活性化を抑制することによりデスミン量の低 下を抑制し, 筋原線維構造を安定化し, 筋萎縮の軽 減を可能にすることが考えられる．しかしながら， このような観点からの検討はこれまで行われていな い.

そこで本研究は, 熱ストレス負荷後, ラットに 6 日間のギプス固定を施し，筋萎縮に対する熱ストレ スの負荷の影響について細胞骨格の一つであるデス ミンを指標に検討することを目的とした .

$$
\text { II. 方法 }
$$

\section{A. 実験動物}

本実験は, 国立大学法人山口大学における動物使 用に関する規則に従い実施した . 実験動物には, 先 行研究 $^{(2)}$ を参考に 6 〜 年月齢のWistar 系雌ラッ 卜 $(\mathrm{n}=13)$ を用いた . 5 日間の予備飼育後, 対照群 $(\mathrm{C}$ 群, $\mathrm{n}=7,361.9 \pm 14.2 \mathrm{~g})$ と熱ストレス群 ( $\mathrm{H}$ 群, $\mathrm{n}=6,370.2 \pm 12.7 \mathrm{~g})$ に体重が等しくなるように群 分けした. H群には, 庫内温度を $42^{\circ} \mathrm{C}$ に設定した恒 温器(ADVANTEC, IS-2400)に, 無麻酔下で 1 時間 放置し熱ストレスを負荷した . 本研究においては, 熱ストレス負荷中の直腸温の経時的変化については 測定していないが, 同樣の方法で行った先行研究で は熱ストレス負荷後, 直腸温は経時的に上昇し，1 時間後の直腸温は $41.6 \pm 0.1^{\circ} \mathrm{C}$ であったことが報告 されている．本研究では, 熱ストレス負荷後サーミ スタ(NIHON KOHDEN, MGA-III)で測定した直腸温

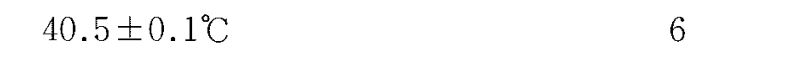
に，C群およびH群の左脚(关れ光れCI 脚およびHI 脚)に, 足関節が底屈位となるように, CASTFLEX$\alpha$ (ALCARE， 15401)を用いてギプス固定を施した .
ラットの生育環境は, 室温 $24 \pm 1^{\circ} \mathrm{C}$, 湿度 $50 \sim 60 \%$ と し，12時間の明暗サイクルを維持した．また，飼育 期間中，ラットには飼料と水を自由に膝取させた .

6 日間のギプス固定後, ラットをエーテル麻酔下 で屠殺し，体重を測定した後，ヒラメ筋(SOL)を摘 出した . 摘出した筋は筋重量を測定し , 分析するま でー80ㄷで涷結保存した。

\section{B．サンプル処理}

凍結した筋の筋腹から50〜100 mg程度筋を切り出 し，切り出した筋の10倍量の Isolation Buffer [20 mM Tris- $\mathrm{HCl}(\mathrm{pH} 7.4), 25 \mathrm{mM} \mathrm{KCl}, 5 \mathrm{mM}$ EDTA, 5 mM EGTA, $1 \mathrm{mM}$ Dithiothreitol, 1\%(v/v) Triton $\mathrm{X}-100,1 \%(\mathrm{v} / \mathrm{v})$ Phosphatase inhibitor cocktail (Nacalai Tesque, 07574-61), 1\%(v/v)Protease inhibitor cocktail(Nacalai Tesque, 25955-11)]を加え， ホモジナイザー(ヤマト科学, OMNI TH)によって均 質化し，遠心分離を行った(3000 rpm， $4^{\circ} \mathrm{C}, 10$ 分). 分離後, 上清を回収した後, 残った沈殿を用い Solaroら ${ }^{15)}$ の方法により筋原線維タンパク質を抽出 した.

抽出後, 可溶性タンパク質濃度はProtein Assay Kit(Bio-Rad，500-0006)により，また筋原線維タン パク質濃度はBiuret法により測定した . 弚の後， タンパク質濃度が $2 \mathrm{mg} / \mathrm{ml}$ にるようにSodiumdodecylsulfate (SDS) sample buffer [62.5 mM Tris- $\mathrm{HCl}(\mathrm{pH} 6.8), 2.3 \%(\mathrm{w} / \mathrm{v}) \mathrm{SDS}, 30 \%(\mathrm{v} / \mathrm{v})$ Glycerol, $0.05 \%(\mathrm{w} / \mathrm{v})$ Bromophenol-blue, $5 \%(\mathrm{v} / \mathrm{v})$ 2-Mercaptoethanol]を用いてサンプルの調整を乥れ ぞれ行った．弚の後，Cool Block Bath（井内， $\mathrm{EC}-40)$ を用いて $60^{\circ} \mathrm{C} て ゙ 10$ 分間加熱した. 調整した サンプルは, 分析を行うまで涷結保存した .

尚，デスミンの分析には筋原線維タンパク質を用 い, 弚の他の分析は可溶性タンパク分画を用い行っ た。

\section{C. ウエスタンブロッティング}

タンパク質は, SDS-PAGE法[7.5\%(w/v) Acrylamide]により分離した . サンプルは, 各レーン当た り $10-20 \mu \mathrm{g}$ を負荷した .なお，泳動されたタンパ ク質量が同程度であったかを確認するためにアクチ ン発現量を指標に検討し, 群間に差がないことを確 認した (結果未掲載). 
電気泳動後 , ミニトランスブロットセル $(\mathrm{Bio}-\mathrm{Rad}$, 170-3930)を用い，100 Vで 1 時間通電を行い，Polyvinylidene difluoride membrane(PVDF膜, Amersham Biosciences, RPN303F)にタンパク質を転写し た. 炎の後, $5 \%(\mathrm{w} / \mathrm{v})$ Skim milk/TTBS[40 mM Tris$\mathrm{HCl}(\mathrm{pH} 7.5), 300 \mathrm{mM} \mathrm{NaCl}, 0.1 \%(\mathrm{v} / \mathrm{v})$ Tween 20] を用いて 1 時間のブロッキング処理を行った .

ブロッキング処理後， $8^{\circ} \mathrm{C}$ に設定したインキュベー ター内で一晚 ,一次抗体反応を行った .一次抗体には， 以下のものを使用した . Desminは , 5\%(w/v)Albmin/ TTBSで1：500に希釈したanti-Desmin(Novocastra, NCL-DES-DER II), Actinは $5 \%(w / v)$ Albmin/TTBS で1：5000に希釈したanti-Actin(Sigma, A3853), Calpain I は, Can Get Signal Solution 1(TOYOBO, NKB-101) で1：1000に希釈したanti-Calpain I(Cell Signaling, 2556), Calpain II はCan Get Signal Solution 1で1：1000に希釈したanti-Calpain II(Sigma, C6111)であった．また，HSP72抗体(StressGen, SPA-812)はTTBSで1：10000に希釈したものを用い た.

一次抗体反応終了後, PVDF 膜を TTBS で10分 $\times$ 3 セット洗浄し，室温で 2 時間，二次抗体反応を行 った . 二次抗体には, 以下のものを使用した . Desminは 5\% Skim milk/TTBSで1：20000に希釈した Anti-Mouse IgG(SIGMA, A4416), Calpain Iおよび Calpain II は, Can Get Signal Solutionで1：20000に 希釈したAnti-Rabbit IgG(SIGMA，A6154)であっ た .また，HSP72 の二次抗体には，TTBSで1：20000 に希釈したAnti-Rabbit IgG ALP(SIGMA，A3687) を用いた。

二次抗体反応終了後, PVDF 膜を TTBS で10分X 3 セット洗浄し, Desmin, Calpain IおよびCalpain IIの検出はECL Plus(GE Healthcare, RPN2132)を 用い目的とするバンドを発光し行った .また ,HSP72 の検出は Alkaline Phosphatase Conjugate Substrate Kit(Bio-Rad，170-6432)を用いて行った .

\section{D. 解析}

発光を行った PVDF 膜は冷却 CCD カメラ (ATTO, Light Capture AE-6961)で, Alkaline Phosphatase

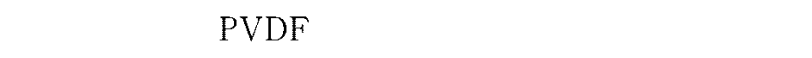
ピュータに取り込み，画像解析ソフト(ATTO, CS Analyzer ver. 2.0)を用いて分析を行い, Desminお
よびHSP72 については，C群の対象脚 $(\mathrm{CC})$ を基準 とし各タンパク質の発現率を比較・検討した.また， Calpain Iと IIについては, 分子量 $80 \mathrm{kDa}$ の total Calpain と光の分解型である分子量 $75 \mathrm{kDa}$ の自己分 解型 (Autolyze)のCalpain 比ならびに光れらの積算 值の合計により，上記と同樣にCCの值を基準とし 発現率を検討した。

\section{E. 統計}

得られたデータは, 全て平均値士標準誤差で表し た. 統計学的分析は, 一元配置の分散分析を行い， 有意差か認められた場合, Tukey 法により群間比較 を行った . 有意水準は全て危険率 $5 \%$ 末満とした .

$$
\text { III. 結果 }
$$

\section{A. 筋重量·相対筋重量}

表 1 に, 筋重量と相対筋重量の結果について示し た . 固定脚の筋重量は C 群ならびにH群ともに低值 を示した $(\mathrm{p}<0.05)$.また，相対筋重量において も筋重量と同樣の結果が得られたのに加え, HI 脚 の相対筋重量はCI 脚よりも有意に高い值であった $(\mathrm{p}<0.05)$.

\section{B. Desmin}

$\mathrm{CI}$ 脚の Desmin 発現率は, $\mathrm{CC}$ 脚ならびに $\mathrm{HC}$ 脚と 比較して有意に低い值であった $(p<0.05)$. しかし ながら，H群では C 脚と I 脚の Desmin 発現率はほ ぼ同じレベルであった (図 1 )。

\section{Calpain I}

図 2 (A)にCalpain I 発現率，(B)に80 kDa Calpain I とAutolyze Calpain I の発現比について光 れした . Calpain I 発現率は，C群ではI 脚 の值は $\mathrm{C}$ 脚の值よりも高い值を示す傾向 $(\mathrm{p}=0.14)$ にあったが，有意な差ではなかった．また，H群で はC 脚と I 脚のCalpain I 発現率は, ほぼ同じレベ ルであった.しかしながら, Autolyze Calpain I比 では CI 脚の值は $\mathrm{CC}$ 脚ならびに $\mathrm{HC}$ 脚よりも有意 $(\mathrm{p}$ $<0.05) に$ 高かった.H群のAutolyze Calpain I比 はC 脚と I 脚で有意差は認められなかった .

\section{Calpain II}

図 3 (A)にCalpain II 発現率, (B)に $80 \mathrm{kDa}$ Cal- 
Table 1. Effects of heat stress on soleus muscle masses and muscle weigh-to-body weight ratios

\begin{tabular}{|c|c|c|c|c|}
\hline & $\mathrm{CC}(\mathrm{n}=7)$ & $\mathrm{CI}(\mathrm{n}=7)$ & $\mathrm{HC}(\mathrm{n}=6)$ & $\mathrm{HI}(\mathrm{n}=6)$ \\
\hline Muscle weight (mg) & $136.1 \pm 9.0$ & $108.1 \pm 7.8^{*}$ & $171.2 \pm 3.7^{*, \dagger}$ & $129.9 \pm 6.1^{\S}$ \\
\hline $\begin{array}{l}\text { Soleus weight-to-body } \\
\text { weight ratio }(\mathrm{mg} / \mathrm{kg})\end{array}$ & $397.3 \pm 15.8$ & $314.6 \pm 13.7^{*}$ & $487.9 \pm 14.9^{*}$, & $369.6 \pm 16.2^{\dagger, 8}$ \\
\hline
\end{tabular}

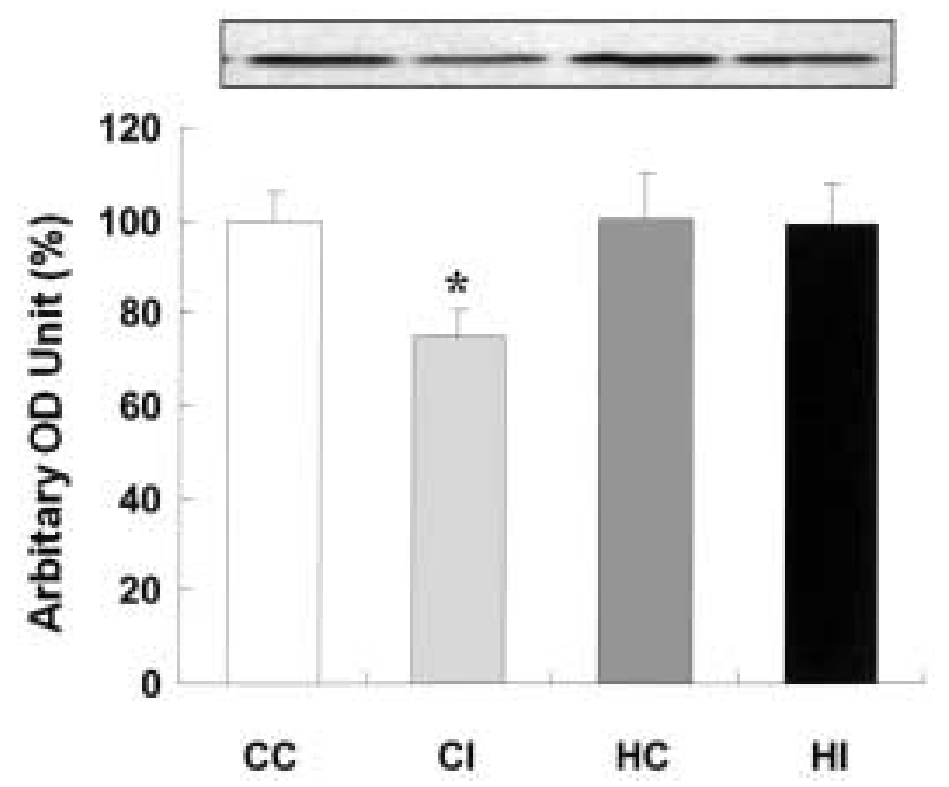

Figure 1. Effects of heat stress on soleus muscle protein levels of desmin in atrophied soleus muscle induced by immobilization of the hind limbs of rats. Values are means $\pm S E ; n=6-7$ animals in each group. ${ }^{*}$ Statistically different $(P<0.05)$ from $C$.

pain II と Autolyze Calpain II の発現比について光 れした . Calpain II 発現率は，いずれの場合 においても有意差は認められなかった . 同樣に , 80 kDa Calpain II とAutolyze Calpain II の発現比に おいても有意差は認められなかった .

\section{E. HSP72}

HSP72 発現率の結果を図 4 に示した.CI脚の HSP72 発現率は, CC 脚ならびに HC 脚と比較して 有意に低い值であった $(\mathrm{p}<0.05)$. しかしながら， H群ではC 脚と I 脚の HSP72 発現率はほぼ同じレベ
ルであった .

$$
\text { N. 考察 }
$$

\section{A. 概要}

本研究は，これまで報告されている熱ストレスの 筋萎縮抑制効果について, 細胞骨格の一つであるデ スミンを指標に検討した初めての研究である . 得ら れた所見は, 熱ストレス負荷が不活動によるカルパ イン活性化の亢進を抑制することによりデスミン発 現量の低下抑制をもたらし，谷の結果，筋萎縮を抑 制することを示唆するものであった . 以下に, 本研 
(A)
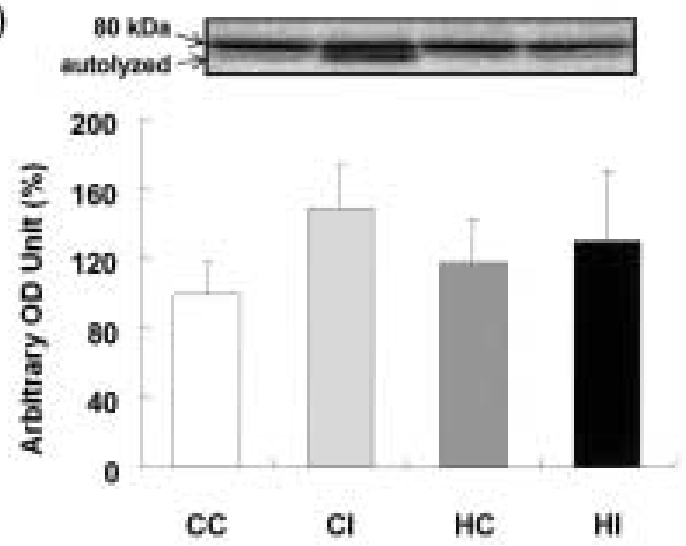

(B)

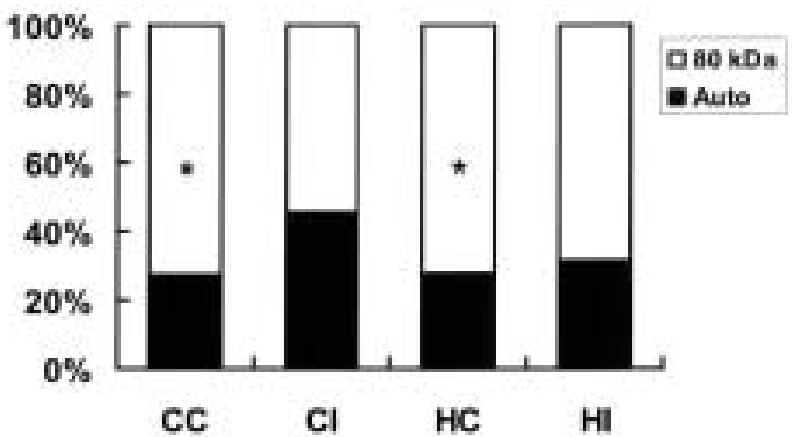

Figure 2. Effects of heat stress on soleus muscle protein levels of calpain I (A) and the ratio of autolyzed and unautolyzed calpains I (B) in atrophied soleus muscle induced by immobilization of the hind limbs of rats. Values are means $\pm S E ; n=6-7$ animals in each group. * Statistically different $(P<0.05)$ from CI.

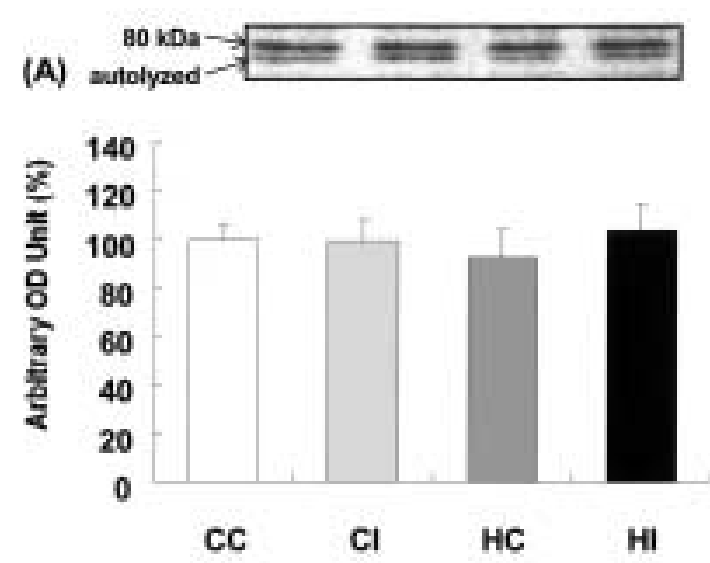

(B)

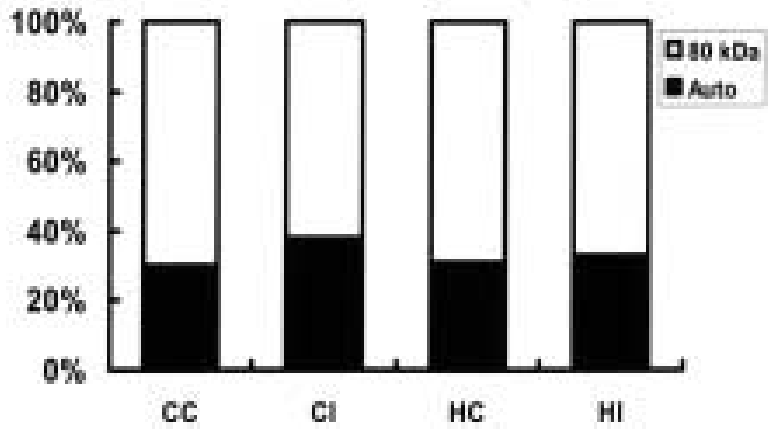

Figure 3. Effects of heat stress on soleus muscle protein levels of calpain II (A) and the ratio of autolyzed and unautolyzed calpains II (B) in atrophied soleus muscle induced by immobilization of the hind limbs of rats. Values are means $\pm \mathrm{SE} ; \mathrm{n}=6-7$ animals in each group.

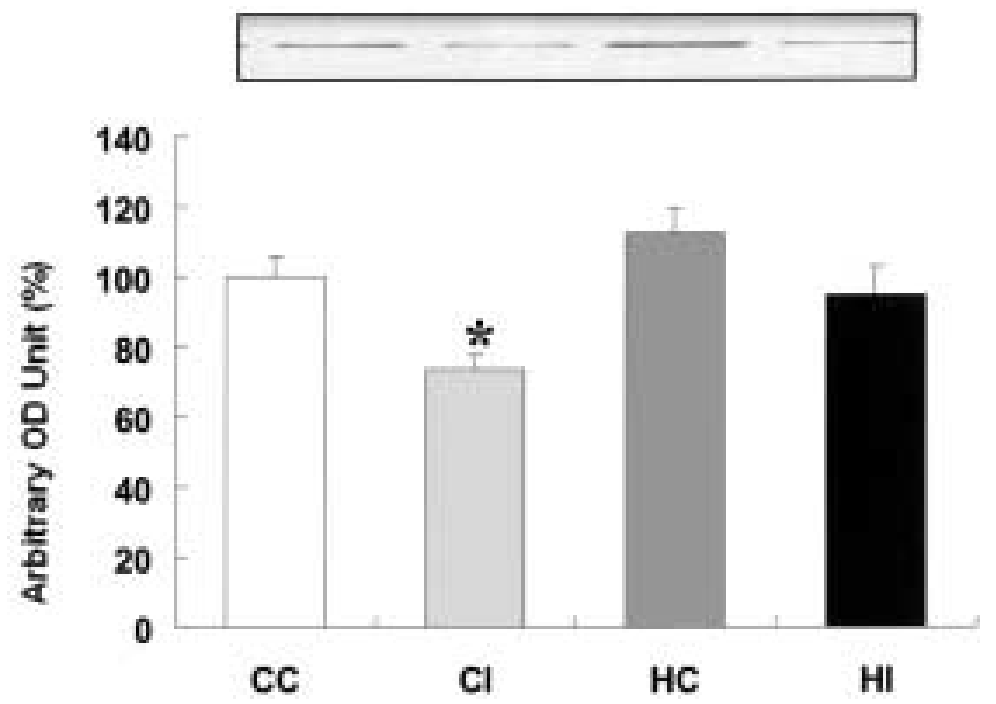

Figure 4. Effects of heat stress on soleus muscle protein levels of HSP72 in atrophied soleus muscle induced by immobilization of the hind limbs of rats. Values are means $\pm \mathrm{SE} ; \mathrm{n}=6-7$ animals in each group. ${ }^{*}$ Statistically different $(P<0.05)$ from $\mathrm{CI}$. 
究の詳細について述べる.

B. ギプス固定が筋重量, カルパイン活性, およ びデスミン動態に及ぼす影響

カルパインには, 細胞内カルシウムイオン濃度が $\mu \mathrm{M}$ レベルで活性化するカルパイン I と $\mathrm{mM}$ レベル で活性化するカルパインIIがあることが知られてい $ろ^{5,6)}$. 通常, 筋における細胞内カルシウムイオン 濃度は約 $0.1 \mu \mathrm{M}$ 以下であり ${ }^{16)}$, カルパイン Iが活 性化するとされるカルシウムイオンレベルは $3 \sim 50$ $\mu \mathrm{M}$, カルパイン II では0.4〜0.8 $\mathrm{mM}$ である ${ }^{5)}$. 力 ルパインは通常，弚の活性化を容易にする為に自己 分解する ${ }^{5,17)}$. また, カルパインの自己分解型は,

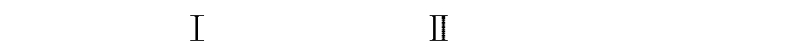
ことも知られており，カルパインの自己分解が起き ているときには, カルパインが活性化しているもの と考えられている5,17).

本研究において, ギプス固定脚の筋重量は, コン トロール脚と比較して低い值となった . また, カル パイン I と II の発現率はいずれの群間においても有 意な変化は見られなかったが, カルパインIでは， 兴の活性化の指標となる自己分解型発現比は, 対照 群の固定脚で高い值を示した .これらのことから， 本研究における固定脚では, カルパイン I 活性化の 六進が起こっていたと考えられる．

更に，ギプス固定を施した脚のデスミン発現量は， 対照脚と比べ低值を示した . デスミンはカルパイン の基質のひとつであり ${ }^{8)}$, 不活動によりカルパイン 活性は元進し，デスミン量が低下し，これらには負 の相関が見られることか報告されている(1). 従って， 本研究で得られた固定脚のデスミン発現量の低下 は, カルパインIの活性化え進により起こり，筋重 量の低下に関係していたと考えられる . Ennsら ${ }^{11)}$ は, 尾部懸垂によるラット大腿四頭筋の萎縮過程に おけるカルパインとデスミンの関係について, カル パイン I 活性は尾部懸垂12時間では既に元進し，デ スミン発現の低下は尾部懸垂24時間後に観察される ことを報告している．これらのことを考慮すると， カルパイン I 活性の亢進と光れに伴うデスミン分解 は，不活動開始初期に起こると考えられる．

また，前述したように，本研究においてカルパイ ンI発現量ならびに自己分解型比は, 固定の影響は 認められなかった . 本研究で得られた所見は, 萎縮
モデルの違いがあるものの, Enns ら ${ }^{11)}$ の報告を支 持するものと考えられる.すなわち，彼らは 9 日間 の尾部懸垂過程においてもカルパイン II 活性は変化 しないことを報告している．このことは, 上述した

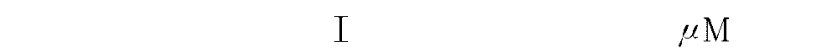

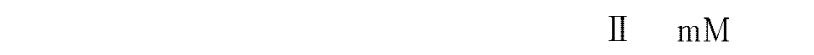
ルで活性化することから ${ }^{5,6)}$, カルパイン II の変化 は長期間の固定により，萎縮がさらに進んだ時点で 見られるのかもしれないが明らかではない .

C. 熱ストレス負荷がカルパイン活性, およびデ スミン動態に及ぼす影響

本研究において, HCの筋重量は CCより有意に増 加していた .このことは，熱ストレス負荷により筋 タンパク質合成が促進し，筋肥大がもたらされたこ とを示す．これまで，熱ストレス負荷が筋タンパク 質合成を促進し筋肥大を招来する機序として，新生 ポリペプチドの折り畳みに関与する HSP72 発現増 加，mRNAの翻訳を促進させタンパク質合成をもた らす Akt/mTOR系シグナル伝達物質のリン酸化え 進，さらには筋衛星細胞の活性化などが示されてい $3^{18)}$. 本研究では, Akt/mTOR系シグナル伝達物質 や筋衛星細胞について検討していないが，HCの HSP72 発現量はCC と比較し有意差は認められないも のの高い值を示す傾向にあったことから $(\mathrm{p}=0.084)$, これらの機序により HCの筋重量がCCよりも高い値 を示したものと考えられる .

不活動が引き起こす筋萎縮への対抗手段として， 近年, 熱ストレス負荷が注目されている.熱ストレ スによって誘導される HSP72 は, 翻訳過程におい て新生ポリペプチドのシャペロンとして機能しタン パク質合成にかかわっているばかりではなく, 酸化 ストレスなどにより一部立体構造が崩れたタンパク 質が再び折りたたまれるのを補助しタンパク質の凝 集を阻止するなどの役割を演じている . Naitoら ${ }^{12)}$ は，尾部懸垂前に熱ストレスを負荷したラットヒラ メ筋では，尾部懸垂による筋萎縮が抑制されたこと を報告し，熱ストレス負荷による HSP72の誘導は， 不活動時の筋タンパク質分解抑制および合成維持に 効果があることを示唆している．また, Selsby ら ${ }^{13)}$ は, 熱ストレス負荷によるHSP72の誘導は, ギプ ス固定によって増大する酸化ストレスを軽減し, 筋 萎縮を抑制することを報告している． 
本研究において，熱ストレスを負荷した固定脚の 相対筋重量は, 熱ストレスを負荷していない固定脚 よりも有意に高い値を示した .また，熱ストレスを 負荷していない固定脚の HSP72 発現量, およびデ スミン発現量は, 両条件でのコントロール脚よりも 有意に低く, カルパイン I 自己分解型発現率は有意 に高かった . 一方, 熱ストレスを負荷した固定脚で は，これらの值はコントロール脚と有意差が見られ なかった .これらのことから，ギプス固定による筋 萎縮に対して熱ストレスを負荷することは, 固定に よるHSP72 発現の低下を抑制し, 酸化ストレスに よる膜タンパク質の変性を阻止することで細胞内力 ルシウムイオン濃度の上昇を抑制することによりカ ルパイン活性の亢進と关の後に起こるデスミンの分 解を抑制し，产の結果筋萎縮を抑制したと考えられ る.さらには, HSP72が持つ変性したタンパク質 の修復機能が関係していたのに加え ${ }^{14)}$, 上述した 熱ストレスによる筋タンパク質合成促進も関与して いたかもしれない．

また，トレーニングした筋では伸張性収縮による 筋損傷を起こしにくく，この機序としてトレーニン グした筋では $Z$ 線周辺に多く発現し筋原線維の微細 構造を維持していると考えられているHSP25や $\alpha$ ーBクリスタリンといった低分子量 HSPが多く発現 していることが報告されていることから ${ }^{19,20)}$, 本 研究においても HSP72以外の HSP も, 熱ストレス による筋萎縮抑制機構に関係しているとも考えられ る.

これまで, 不活動により HSP72 発現量は低下する が，不活動前に熱ストレスを負荷することにより HSP72 発現量の低下を抑制することが報告されてい $3^{12)}$.本研究においても対照群では, 固定脚のHSP72 発現量は対照脚よりも有意に低かったのに対し，熱 ストレス群では対照脚と固定脚の間には有意な差は 認められなかった . 不活動あるいは不動化により招 来される筋萎縮中の HSP72 の低下の原因については 明らかではないが, HSP72発現量は筋活動量と密接 な関係にある ${ }^{14,21)}$ ことから，不活動(不動化)による 筋活動の低下の影響か酸化ストレスによる HSP72 発 現量の増加よりも優位だったことによると推察され る・また，熱ストレスを負荷することにより，この ようなHSP72 発現量の低下を抑制したものと考えら れる .

$$
\text { V. 結語 }
$$

本研究は, 熱ストレス負荷 $\left(42^{\circ} \mathrm{C}, 60\right.$ 分 $)$ の筋萎縮 抑制効果について，6〜8 ケ月齢のWistar 系雌ラッ 卜のヒラメ筋を被検筋に，細胞骨格の一つであるデ スミンを指標に検討した。

谷の結果, 熱ストレス負荷による筋萎縮抑制の要 因の一つとして，熱ストレス負荷が不動化による HSP72 発現量の低下を抑制することによりカルパイ ンの活性化を抑制し, 光の結果, デスミン分解が抑 制されたことによりもたらされたと考えられた．

\section{謝 辞}

本研究の実施に際し, 多大な協力を頂いた本研究室海 老原薰さんに深謝する.また, 本研究の一部は, 平成20 年度科学研究費補助金基盤研究 (C) (杉浦, 課題番号, 20500578), 平成18年度科学研究費補助金基盤研究 (A) (去 岡, 課題番号 18200042)ならびに平成21年度山口大学教 育学部研究支援経費によって実施された。

\section{(受理日 平成21年12月22日)}

文献

1) Thomason D.B., Booth F.W. Atrophy of the soleus muscle by hindlimb unweighting. J Appl Physiol. (1990), 68, $1-12$.

2) Kondo H., Kodama J., Kishibe T., Itokawa Y. Oxidative stress during recovery from muscle atrophy. FEBS Lett. (1993), 326, 189-191.

3) Ingalls C.P., Wenke J.C., Armstrong R.B. Time course changes in $[\mathrm{Ca} 2+] \mathrm{i}$, force, and protein content in hindlimb-suspended mouse soleus muscles. Aviat Space Environ Med. (2001), 72, 471-476.

4) Powers S.K., Kavazis A.N., McClung J.M. Oxidative stress and disuse muscle atrophy. J Appl Physiol. (2007), 102, 2389-2397.

5) Goll D.E., Thompson V.F., Li H., Wei W., Cong J. The Calpain System. Physiol Rev, (2003), 83, 731-801.

6) 小野弥子. 反町洋之. 鈴木紘一. タンパク質分解一 分子機構と細胞機能一, 第 1 版, カルパイン-カルパ スタチン系, シュプリンガー・フェアラーク東京株式 会社, 東京, (2000), 59-70.

7) Wang K., Ramirez-Mitchell R. A network of transverse and longitudinal intermediate filaments is associated with sarcomeres of adult vertebrate skeletal muscle. J Cell Biol. (1983), 96, 562-570.

8) 野坂和則. 運動分子生物学, 第 1 版, 細胞骨格, ナッ プ, 東京, (2000), 43-62.

9) Li Z., Mericskay M., Agbulut O., Butler-Browne G., Carlsson L., Thornell L.E., Babinet C., Paulin D. Desmin 
is essential for the tensile strength and integrity of myofibrils but not for myogenic commitment, differentiation, and fusion of skeletal muscle. J Cell Biol. (1997), 139, 129-144.

10) Wagatsuma K. Effect of hindlimb immobilization on , 術研究紀要 (2007) , 36, 17-23.

11) Enns D.L., Raastad T., Ugelstad I., Belcastro A.N. Calpain/calpastatin activities and substrate depletion patterns during hindlimb unweighting and reweighting in skeletal muscle. Eur J Appl Physiol. (2007), 100, 445-455.

12) Naito H., Powers S.K., Demirel H.A., Sugiura T., Dodd S.L., Aoki J. Heat stress attenuates skeletal muscle atrophy in hindlimb-unweighted rats. J Appl Physiol. (2000), 88, 359-363.

13) Selsby J.T., Dodd S.L. Heat treatment reduces oxidatie stress and protects muscle mass during immobilization. Am J Physiol Regul Inger Comp Physiol. (2005), 289, 134- 139.

14) 内藤久士 . 小林裕幸 . 運動とタンパク質 遺伝子, 第 1 版, 骨格筋におけるストレスタンパク質の発現と その役割，ナップ，東京，(2004)，167-180.
15) Solaro R.J., Pang D.C., Briggs F.N. The purification of cardiac myofibrils with Triton X-100. Biochim Biophys Acta. (1971), 245, 259-262.

16 ) 後藤勝正. 運動分子生物学, 第 1 版, 運動と横行小管 一筋小胞体，ナップ，東京，(2000)，89-104.

17) Vermaelen M., Sirvent P., Raynaud F., Astier C., Mercier J., Lacampagne A., Cazorla O. Differential localization of autolyzed calpains 1 and 2 in slow and fast skeletal muscles in the early phase of atrophy. Am J Physiol Cell Physiol. (2007), 292, 1723-1731.

18) 杉浦崇夫, 後藤勝正, 内藤久士 . 筋損傷からの回復 を促す温熱刺激，体育の科学。(2006)，56，714-719.

19) Koh T.J. Do small heat shock proteins protect skeletal muscle from injury?. Exerc Sports Sci Rev. (2002), 30, 117-121.

20) Koh T.J., Escobedo J. Cytoskeletal disruption and small heat shock protein translocation immediately after lengthening contractions. Am J Physiol Cell Physiol. (2004), 286, 713-722.

21) 轟木一弘, 杉浦崇夫, 後藤勝正, 内藤久士 , 吉岡利忠 . 異なる速度での一過性の走運動とトレーニングに伴 うラット骨格筋の熱ショックタンパク質発現量の変 化 , 体力科学 . (2004), $53,537-547$. 